\title{
Integrated effect of organic waste and NPK fertilizers on nutrients uptake in potato crop and soil fertility
}

\author{
Muhammad Zahoor ${ }^{1}$, Naseem Khan ${ }^{1}$, Murad $\mathrm{Ali}^{2 *}$, Muhammad Saeed ${ }^{2}$, \\ Zia Ullah ${ }^{3}$, Muhammad Adnan ${ }^{4}$ and Bashir Ahmad ${ }^{5}$ \\ 1. Department of Soil and Environmental Sciences, University of Agriculture, Peshawar, Pakistan \\ 2. Cereal Crops Research Institute Pirsabak, Nowshera, Pakistan \\ 3. Department of water management, University of Agriculture, Peshawar, Pakistan \\ 4. Department of Agriculture, University of Swabi, Pakistan \\ 5. Directorate of Outreach, Agric. Research System, Khyber Pakhtunkhwa, Peshawar, Pakistan \\ *Corresponding author's e-mail: muradses@ gmail.com \\ Citation \\ Muhammad Zahoor, Naseem Khan, Murad Ali, Muhammad Saeed, Zia Ullah, Muhammad Adnan and Bashir \\ Ahmad. Integrated effect of organic waste and NPK fertilizers on nutrients uptake in potato crop and soil fertility. \\ Pure and Applied Biology. Vol.5, Issue 3, pp601-607. http://dx.doi.org/10.19045/bspab.2016.50078
}

Received: 21/01/2016 Revised: 03/06/2016

Accepted: 10/06/2016

Online First: 17/06/2016

\section{Abstract}

The present research was carried out at Nuclear Institute of Food and Agriculture (NIFA), Peshawar Pakistan, to evaluate the integrated response of organic waste and N-P-K fertilizers to nutrients concentration in potato tuber and soil fertility. Fifteen treatment combinations with three replications were used in RCB design. Potato tubers and soil samples (0-15 and 15-30 cm depth) was collected before and after the experiment were analyzed. Data indicated that combined use of organic waste and N-P-K fertilizers significantly improved soil fertility and nutrients concentration

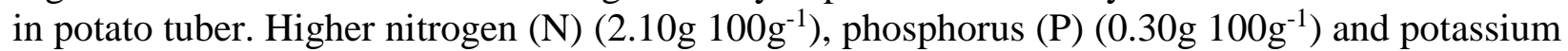

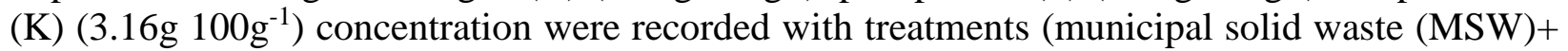
half NPK) and (Filter cake +full NPK) as compared to control. Maximum total soil N, AB-DTPA extractable $\mathrm{P}, \mathrm{K}$ and micronutrients were recorded with (MSW+ half NPK) and (Filter cake +full NPK) at both depths. Investigation revealed that the combined use of organic waste and chemical fertilizers beneficial to soil and plant. Moreover, treatments (MSW +full NPK) and (Filter cake + full NPK) seemed to be an adequate dose, for sustainable nutrients concentration in potato tuber and soil fertility.

Key words: Potato; Organic waste; NPK fertilizer; Organic matter; Micronutrients

\section{Introduction}

Pakistan is an agriculture country and most of the people are related to agriculture sector. According to an estimate, less than $1 \%$ organic matter is present and $100 \%$ of soil is deficient of some nutrients. Application of organic manure not only improving soil fertility but also enhance crop productivity when available to crop at approprate level [1]. Organic matter play a multi role in soil, such as increasing of organic matter and to release the nutrients throughout in growing plant; also increase the mobility of moisture, interm of water holding capacity (AWHC) and buffering capacity of soil [2]. Crops residue, municipal waste enhance physico-chemical 
properties and fertility status of soil, resulting better productivity [3]. Composts are also indispensible to maximize organic matter in those area where organic matter contents are very low. The main causes of low production in Pakistan are nutrients deficiencies, improper use of chemical fertilizers, low organic matter and poor physical condition of soil [4]. Balance use of synthetic fertilizers are essential to get economical produce, while imbalance and improper time application, significantly loss most of essential nutrients from the soil through leaching and volatilization [5].

Potato is an important crop of world, including Pakistan, ranked on $4^{\text {th }}$ in the world and $7^{\text {th }}$ in Pakistan. It is mostly cultivated in hilly area of North West Khyber Pakhtunkhwa and plain of Punjab. Potato crop can be cultivated in a year three times such as spring and in the plain area it is grown in autumn while in the hilly area in summer. In Pakistan it is cultivated on area of 0.14 million hectares, with total production of 2.55 million tons, while in Khyber Pakhtunkhwa (KPK) it is cultivated on 9.20 thousand hectares and with total production is 0.12 million tons. In Pakistan average yield per hectare is 22.7 tons, while in KPK the average yield per hectare is 13.1 tons [6]. Due to low soil fertility and nutrients deficiency fertilizer use is very important to increase crop production. Potato yield and quality increases through application of NPK fertilizers. Application of potassium fertilizers increases quality of potato tuber and production [7]. The efficiency of N-P-K fertilizers can be increased with the combine use of organic manure [8]. The main objective of present work was to study response of different doses of fertilizers to nutritional composition of local variety of potato (Core), observed soil fertility and quality of potato through best combination of organic waste and mineral fertilizers.

\section{Materials and methods}

\section{Location}

Experiment was carried out at research field of NIFA Tarnab, situated at longitude $71^{0} 50$ and latitude $34^{\circ} 01$, Peshawar, Pakistan during autumn season 2012. The experimental site was located on $400 \mathrm{~m}$ altitude near Peshawar having cooled in winter and warm to hot in summer. Soil samples were collected from 0-15 and 15-30 $\mathrm{cm}$ depths to analysis the Physico-chemical properties of site are presented in Table 1 .

\section{Field procedure and treatment}

The experiment consisted of fifteen treatments combination, using appropriate RCB design, replicated thrice. Ridges was made and potato were sown on $30 \mathrm{~cm}$ high and ridges distance was kept $80 \mathrm{~cm}$. Different treatments combinations including control, farm yard manure, municipal solid waste, NPK full, tomato residue + half NPK, filter cake + half NPK, tomato residue + full NPK, filter cake + full NPK, recommended PK, tomato residue alone, filter cake alone, (farm yard manure) FYM + half NPK, MSW + half NPK, FYM + full NPK and MSW + full NPK. All $P$ and $K$ were applied at the time of sowing while $\mathrm{N}$ was applied in split, half at sowing and half at the time of earthing off.

\section{Statistical analysis}

Means were separated using Duncan's Multiple Range Tests at 0.05 level of probability as $\mathrm{F}$ - ratio was significant. 
Table 1. Physico-chemical properties of the research site

\begin{tabular}{|l|c|c|c|}
\hline \multicolumn{1}{|c|}{ Properties } & Units & \multicolumn{2}{c|}{ Experimental Sites } \\
\hline Sand & & $0-15 \mathrm{~cm}$ & $15-30 \mathrm{~cm}$ \\
\hline Silt & $\%$ & 20 & 20 \\
\hline Clay & $\%$ & 46 & 40 \\
\hline Texture Class & $\%$ & 34 & 40 \\
\hline pH(1:5) & & Clay loam & Clay loam \\
\hline Electrical Conductivity & $\mathrm{dS} \mathrm{m}$ & 8.2 & 8.2 \\
\hline organic matter & $\mathrm{mg} \mathrm{kg}^{-1}$ & 2.73 & 2.4 \\
\hline Total nitrogen & $\mathrm{mg} \mathrm{kg}^{-1}$ & 0.94 & 0.9 \\
\hline Phosphorous & $\mathrm{mg} \mathrm{kg}^{-1}$ & 0.84 & 0.74 \\
\hline Potassium & $\mathrm{mg} \mathrm{kg}^{-1}$ & 8.75 & 6.9 \\
\hline Zinc & $\mathrm{mg} \mathrm{kg}^{-1}$ & 80 & 1.45 \\
\hline Copper & $\mathrm{mg} \mathrm{kg}^{-1}$ & 1.71 & 7.3 \\
\hline Iron & $\mathrm{mg} \mathrm{kg}^{-1}$ & 8.52 & 5.01 \\
\hline Manganese & $\mathrm{mg} \mathrm{kg}^{-1}$ & 5.45 & 10.5 \\
\hline
\end{tabular}

\section{Results and discussions Organic matter and NPK concentration in soil}

Data showed that treatment combinations significantly $(\mathrm{P} \leq 0.05)$ affect the total $\mathrm{N}, \mathrm{AB}$ DTPA extractable $\mathrm{P}$ and $\mathrm{K}$ as compared to control (Table 2). At depth of $0-15 \mathrm{~cm}$ maximum total $\mathrm{N}$ concentration $(0.083 \mathrm{~g}$ $\left.100 \mathrm{~g}^{-1}\right)$ was recorded in those treatments which were treated with (Filter cake+ full NPK) and statistically similar to those treatments which were received Tomato remains+ full NPK, MSW+ full NPK and similar trend was found for $15-30 \mathrm{~cm}$ depth. The AB-DTPA extractable P $\left(11.2 \mathrm{mg} \mathrm{Kg}^{-1}\right)$ was observed higher in treatment (half NPK +Filter cake) at depths of $0-15 \mathrm{~cm}$ and 15 $30 \mathrm{~cm}$. High AB-DTPA extractable K $(176.8$ and $\left.113.3 \mathrm{mg} \mathrm{Kg}^{-1}\right)$ was recorded in the treatment (full NPK+ Filter cake) at two soil depths at $0-15$ and $15-30 \mathrm{~cm}$ respectively. The highest organic matter in the soil was

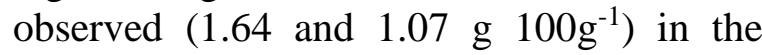
treatment (full NPK +Filter cake) at soil depths at 0-15 and $15-30 \mathrm{~cm}$ simultaneously. At the depths of $0-15 \mathrm{~cm}$ and $15-30 \mathrm{~cm}$ the minimum concentrations of total $\mathrm{N}, \mathrm{AB}-$ DTPA extractable $\mathrm{P}$ and $\mathrm{K}$ and soil organic matter were observed. The balance supply of the major three nutrients required for plant growth and development, there might be a significant increase in total $\mathrm{N}$ concentration [9].

Influence of organic waste and NPK fertilizer on NPK concentration in potato tuber

N-P-K fertilizers and organic waste significantly $(\mathrm{P} \leq 0.05)$ increases NPK application in potato tuber as compared to control treatment. Statistically higher $\mathrm{N}$ concentration was perceived $\left(2.10{\left.\mathrm{~g} 100 \mathrm{~g}^{-1}\right)}^{-1}\right.$ in treatment which received half NPK+ MSW and was different from rest of the treatments and lowest in control as shown in Table 3. The maximum $P$ concentration $(0.30$ $\mathrm{g} 100 \mathrm{~g}^{-1}$ ) was recorded in treatment combination which was applied Filter cake + full NPK dose and lowest was recorded in

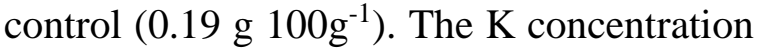

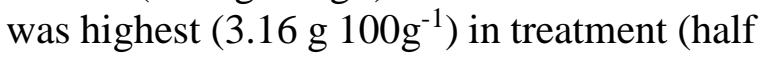
NPK +MSW) and lowest in control $\left(2.0 \mathrm{~g} 100 \mathrm{~g}^{-1}\right)$. 
Table 2. Effect of organic waste and NPK fertilizers on soil organic matter and NPK concentration in soil

\begin{tabular}{|c|c|c|c|c|c|c|c|c|}
\hline \multirow[t]{2}{*}{ Treatments } & \multicolumn{2}{|c|}{$N\left(g 1_{100 g}^{-1}\right)$} & \multicolumn{2}{|c|}{$P\left(\mathbf{m g ~ K g} \mathbf{~}^{-1}\right)$} & \multicolumn{2}{|c|}{$K\left(m g K^{-1}\right)$} & \multicolumn{2}{|c|}{$\operatorname{SOM}\left({\mathrm{g} 100 \mathrm{~g}^{-1}}^{-1}\right)$} \\
\hline & $0-15 \mathrm{~cm}$ & $15-30 \mathrm{~cm}$ & $0-15$ & $15-30$ & $0-15$ & $15-30$ & $0-15$ & $15-30$ \\
\hline Control & $0.049 \mathrm{i}$ & $0.043 \mathrm{e}$ & $5.1 \mathrm{i}$ & $4.16 \mathrm{e}$ & $100 f$ & $50.0 \mathrm{f}$ & $0.63 \mathrm{j}$ & $0.40 \mathrm{~g}$ \\
\hline P-K Recommended & $0.056 \mathrm{gh}$ & $0.055 \mathrm{~d}$ & $6.1 \mathrm{~h}$ & $4.8 \mathrm{~d}$ & $120.0 \mathrm{e}$ & 66.6ef & $0.77 \mathrm{~h}$ & 0.63 de \\
\hline FYM alone & $0.060 \mathrm{fg}$ & $0.056 \mathrm{~d}$ & $9.8 \mathrm{~cd}$ & $6.0 \mathrm{c}$ & $143.3 \mathrm{~cd}$ & 73.3de & $0.84 \mathrm{~g}$ & $0.77 \mathrm{c}$ \\
\hline Tomato residue & $0.053 \mathrm{~h}$ & $0.058 \mathrm{~d}$ & $7.2 \mathrm{~g}$ & $4.8 \mathrm{~d}$ & $110.0 \mathrm{ef}$ & $60.0 \mathrm{ef}$ & $0.64 j$ & $0.54 \mathrm{f}$ \\
\hline Munciple solid waste & $0.064 \mathrm{e}$ & 0.056 & $11.2 \mathrm{a}$ & $5.1 d$ & $120.0 \mathrm{e}$ & $86.6 \mathrm{~cd}$ & $1.06 \mathrm{de}$ & $0.80 \mathrm{c}$ \\
\hline Filter Cake & $0.064 \mathrm{e}$ & $0.060 \mathrm{~cd}$ & $9.8 \mathrm{~cd}$ & $6.2 \mathrm{c}$ & $113.3 \mathrm{ef}$ & $86.6 \mathrm{~cd}$ & $0.97 f$ & $0.64 d$ \\
\hline NPK recommend & $0.066 \mathrm{de}$ & $0.058 \mathrm{~cd}$ & $8.1 \mathrm{f}$ & $6.3 c$ & $153.3 \mathrm{bcd}$ & $93.3 b c$ & $1.04 \mathrm{e}$ & $0.56 \mathrm{ef}$ \\
\hline FYM+ half NPK & $0.063 \mathrm{ef}$ & $0.059 \mathrm{~cd}$ & $9.5 \mathrm{de}$ & $5.1 \mathrm{~d}$ & $150.0 \mathrm{bcd}$ & $106.6 \mathrm{ab}$ & $0.72 \mathrm{i}$ & 0.59def \\
\hline Tomato residue + half NPK & $0.062 \mathrm{ef}$ & $0.059 \mathrm{~cd}$ & $9.1 \mathrm{e}$ & $5.0 \mathrm{~d}$ & $110.0 \mathrm{ef}$ & $86.6 \mathrm{~cd}$ & $0.87 \mathrm{~g}$ & $0.47 \mathrm{~g}$ \\
\hline MSW + half NPK & $0.069 \mathrm{~cd}$ & $0.063 b c$ & $10.4 b$ & $6.0 \mathrm{c}$ & $146.6 \mathrm{bcd}$ & $93.3 \mathrm{bc}$ & $1.30 \mathrm{c}$ & $0.63 \mathrm{de}$ \\
\hline filter Cake + half NPK & $0.071 \mathrm{c}$ & $0.066 b$ & $11.2 \mathrm{a}$ & $7.2 b$ & $146.6 \mathrm{bcd}$ & $100.0 \mathrm{bc}$ & $1.10 \mathrm{~d}$ & $0.59 \mathrm{def}$ \\
\hline FYM + full NPK & $0.076 b$ & $0.072 \mathrm{a}$ & $10.1 \mathrm{bc}$ & $8.1 \mathrm{a}$ & $156.6 b c$ & $106.6 \mathrm{ab}$ & $1.65 \mathrm{a}$ & $0.80 \mathrm{c}$ \\
\hline Tomato residue + full NPK & $0.081 \mathrm{a}$ & $0.074 \mathrm{a}$ & $9.6 \mathrm{~cd}$ & $6.1 \mathrm{c}$ & $140.0 \mathrm{~d}$ & $93.3 \mathrm{bc}$ & $1.64 \mathrm{a}$ & $0.97 b$ \\
\hline MSW + full NPK & $0.080 \mathrm{a}$ & $0.072 \mathrm{a}$ & $11.4 \mathrm{~b}$ & $5.0 \mathrm{~d}$ & $160.0 \mathrm{~b}$ & $106.6 \mathrm{ab}$ & $1.50 \mathrm{~b}$ & $1.07 \mathrm{a}$ \\
\hline Filter cake + NPK full & $0.083 \mathrm{a}$ & $0.067 \mathrm{a}$ & $8.1 \mathrm{f}$ & $8.1 \mathrm{a}$ & $176.8 \mathrm{a}$ & $113.3 \mathrm{a}$ & $1.64 \mathrm{a}$ & $1.07 \mathrm{a}$ \\
\hline LSD 0.05 & 0.003 & 0.005 & 0.48 & 0.48 & 13.5 & 17.6 & 0.047 & 0.075 \\
\hline
\end{tabular}


The NPK application was considerably enriched in potato tuber by the accumulation of organic waste and NPK fertilizers. The results are in general agreement with the findings of $[10]$, who reported that farm yard manure when subjected to the soil, results in boosting of carbon mineralization from the soil due to available carbon for microbial respiration, providing of nitrogen and phosphorus.

Table 3. Effect of organic waste and NPK fertilizer on NPK concentration in potato tuber

\begin{tabular}{|l|c|c|c|}
\hline Treatments & $\mathbf{N}\left(\mathbf{g ~ 1 0 0 g}^{-1}\right)$ & $\mathbf{P}\left(\mathbf{g ~ 1 0 0 g}^{-1}\right)$ & $\mathbf{K}\left(\mathbf{g ~ 1 0 0 g}^{-\mathbf{1}}\right)$ \\
\hline Control & $1.50 \mathrm{f}$ & $0.19 \mathrm{~d}$ & $2.00 \mathrm{~cd}$ \\
\hline P-K recommended & $1.53 \mathrm{ef}$ & $0.26 \mathrm{~b}$ & $2.16 \mathrm{bcd}$ \\
\hline FYM & $1.68 \mathrm{~d}$ & $0.240 \mathrm{bc}$ & $2.16 \mathrm{bcd}$ \\
\hline Tomato residue & $1.42 \mathrm{~g}$ & $0.240 \mathrm{bc}$ & $2.33 \mathrm{bcd}$ \\
\hline Munciple solid waste & $1.55 \mathrm{ef}$ & $0.21 \mathrm{~cd}$ & $2.50 \mathrm{abcd}$ \\
\hline Filter Cake & $1.59 \mathrm{e}$ & $0.21 \mathrm{~cd}$ & $1.83 \mathrm{~d}$ \\
\hline NPK recommended & $1.57 \mathrm{ef}$ & $0.240 \mathrm{bc}$ & $2.50 \mathrm{abcd}$ \\
\hline FYM + half NPK & $1.88 \mathrm{c}$ & $0.20 \mathrm{~cd}$ & $2.66 \mathrm{abc}$ \\
\hline Tomato residue + half NPK & $1.73 \mathrm{~d}$ & $0.25 \mathrm{bc}$ & $2.16 \mathrm{bcd}$ \\
\hline MSW + half NPK & $2.10 \mathrm{a}$ & $0.24 \mathrm{bc}$ & $2.50 \mathrm{abcd}$ \\
\hline Filter Cake + half NPK & $1.59 \mathrm{e}$ & $0.25 \mathrm{bc}$ & $2.50 \mathrm{abcd}$ \\
\hline FYM +full NPK & $1.87 \mathrm{c}$ & $0.24 \mathrm{bc}$ & $2.33 \mathrm{bcd}$ \\
\hline Tomato residue + full NPK & $1.57 \mathrm{e}$ & $0.26 \mathrm{~b}$ & $2.83 \mathrm{ab}$ \\
\hline MSW+ full NPK & $2.01 \mathrm{~b}$ & $0.25 \mathrm{~b}$ & $3.16 \mathrm{a}$ \\
\hline Filter cake + NPK full & $2.04 \mathrm{ab}$ & $0.30 \mathrm{a}$ & $2.66 \mathrm{abc}$ \\
\hline LSD 0.05 & $\mathbf{0 . 0 7 1}$ & $\mathbf{0 . 0 3 8}$ & $\mathbf{0 . 7 2}$ \\
\hline
\end{tabular}

Effect of NPK fertilizers and organic waste on micronutrients concentration in potato tuber.

Data showed that the concentration of micronutrient $(\mathrm{Cu}, \mathrm{Zn}, \mathrm{Fe}$ and $\mathrm{Mn})$ in potato tuber was significantly $(\mathrm{P} \leq 0.05)$ increased with NPK fertilizer and organic waste compared to control treatment (table 4). The Maximum concentration of zinc $(23.50 \mathrm{mg}$ $\mathrm{Kg}^{-1}$ ) was observed in the treatment where only Tomato residue was applied and minimum $\left(2.73 \mathrm{mg} \mathrm{Kg}^{-1}\right)$ was recorded in control. The treatment in which PK of the recommended dose was applied showed highest $\mathrm{Cu}$ concentration $\left(4.13 \mathrm{mg} \mathrm{Kg}^{-1}\right)$ while lower concentration $\left(0.16 \mathrm{mg} \mathrm{Kg}^{-1}\right)$ was observed in control. The treatment in which Filter cake + full was used showed higher concentration of $\mathrm{Fe}\left(1147.3 \mathrm{mg} \mathrm{Kg}^{-1}\right)$ and lowest concentration of iron $(1095.3 \mathrm{mg}$ $\mathrm{Kg}^{-1}$ ) was noted in control. The $\mathrm{Mn}$ concentration was in the range of 0.050 $0.088 \mathrm{mg} \mathrm{Kg}^{-1}$, the highest Mn concentration was recorded in treatment where MSW + full NPK were applied and lowest in control. The extractable concentrations of $(\mathrm{Zn}, \mathrm{Fe}, \mathrm{Cu}$, and $\mathrm{Mn}$ ) in the potato tuber were considerably enhanced with combined use of NPK organic and waste as compare to control and other treatments. The micronutrients concentration is increases with addition of organic waste the same results were reported by [11] who reported that addition of organic material increased micronutrient concentration in soil and enhanced their uptake positively. The results are also in line with finding of [12]. 
Table 4. Effect of organic waste and NPK fertilizers on $\mathrm{Zn}, \mathrm{Cu}$, Fe and $\mathrm{Mn}$ concentration in potato tuber

\begin{tabular}{|c|c|c|c|c|}
\hline & $\mathrm{Zn}\left(\mathrm{mg} \mathrm{Kg} \mathrm{g}^{-1}\right)$ & $\mathrm{Cu}\left(\mathrm{mg} \mathrm{Kg} \mathrm{g}^{-1}\right)$ & $\mathrm{Fe}\left(\mathrm{mg} \mathrm{Kg} \mathrm{g}^{-1}\right)$ & $\operatorname{Mn}\left(\mathrm{mg} \mathrm{Kg} \mathrm{g}^{-1}\right)$ \\
\hline Control & $2.73 \mathrm{j}$ & $0.16 \mathrm{e}$ & $1095.3 \mathrm{bcd}$ & $0.050 \mathrm{~b}$ \\
\hline $\mathrm{P}-\mathrm{K}$ recommended & $10.96 \mathrm{~h}$ & $4.13 \mathrm{a}$ & 1119.7abcd & $0.068 \mathrm{ab}$ \\
\hline FYM & $22.00 \mathrm{ab}$ & $2.23 b$ & $1075.3 d$ & $0.085 \mathrm{a}$ \\
\hline Tomato residue & $23.50 \mathrm{a}$ & $2.70 \mathrm{~b}$ & 1139.3ab & $0.070 \mathrm{ab}$ \\
\hline Munciple solid waste & $7.03 \mathrm{i}$ & $0.50 \mathrm{de}$ & 1108.0abcd & $0.077 \mathrm{ab}$ \\
\hline Filter Cake & 19.00bcdef & $0.73 d$ & $1086.7 \mathrm{~cd}$ & $0.070 \mathrm{ab}$ \\
\hline NPK recommended & $16.56 \mathrm{defg}$ & $0.43 \mathrm{de}$ & $1085.7 \mathrm{~cd}$ & $0.072 \mathrm{ab}$ \\
\hline FYM + half NPK & $6.067 \mathrm{ij}$ & $1.46 \mathrm{c}$ & $1137.7 \mathrm{ab}$ & $0.072 \mathrm{ab}$ \\
\hline Tomato residue + half NPK & $21.00 \mathrm{abc}$ & $1.73 c$ & 1115.7abcd & $0.078 \mathrm{ab}$ \\
\hline MSW + half NPK & $17.33 \mathrm{cdef}$ & $0.56 \mathrm{de}$ & $1121.7 \mathrm{abcd}$ & $0.067 \mathrm{ab}$ \\
\hline Filter Cake + half NPK & $15.33 \mathrm{fg}$ & $0.40 \mathrm{de}$ & 1096.0bcd & $0.067 \mathrm{ab}$ \\
\hline FYM +full NPK & $13.00 \mathrm{gh}$ & $1.40 \mathrm{c}$ & 1102.0abcd & $0.0703 \mathrm{ab}$ \\
\hline Tomato residue + full NPK & $16.33 \mathrm{efg}$ & $4.00 \mathrm{a}$ & 1131.0abc & $0.072 \mathrm{ab}$ \\
\hline MSW+ full NPK & 20.00abcd & $1.33 \mathrm{c}$ & $1130.0 \mathrm{abc}$ & $0.088 \mathrm{a}$ \\
\hline Filter cake + NPK full & 20.33abcd & $0.63 \mathrm{de}$ & $1147.3 \mathrm{a}$ & $0.077 \mathrm{ab}$ \\
\hline LSD 0.05 & 3.92 & 0.46 & 50.79 & 0.03 \\
\hline
\end{tabular}

\section{Conclusions}

It is concluded from the above result that use of organic waste significantly improved soil organic matter, nitrogen, Phosphorous and Potassium ingredients in soil and tuber were significantly improved with the application of Filter cake + Full NPK and Full NPK + MSW in treatments respectively. Hence the long term use of organic and inorganic fertilizers will be beneficial in achieving sustainable yield.

\section{Authors' contribution}

Conceived and designed the experiments: $M$ Zahoor, Performed the experiments: M Zahoor \& N Khan, Analyzed the data: M Ali $\&$ M Adnan, Contributed reagents/ materials/ analysis tools: M Saeed, Z Ullah \& B Ahmad, Wrote the paper: M Ali \& M Saeed.

\section{References}

1. Pedra F, Polo A, Ribeiro A \& Domingues $H$ (2007). Effects of municipal solid waste compost and sewage sludge on mineralization of soil organic matter. Soil Biol Biochem. 39: 1375-1382.

2. Upadhayay NC \& Singh JP (2003). The Potato (Production and utilization in SubTropics) Edited by SM Paul Khurana, JS. Minhas and SK Pandey. Published by Mehta Publishers, A 16(East), Naraina II, New Delhi-110028, India.

3. Sposito GL, Lund J \& Chang AC (1982). Trace metal chemistry in arid-zone field soils amended with sewage sludge: fractionation of $\mathrm{Ni}, \mathrm{Cu}, \mathrm{Zn}, \mathrm{Cd}$. and $\mathrm{Pb}$ in solid phases. Soil Sci Soc Am J 46: 260264.

4. Rashid A (1994). Annual report of micronutrient project, Land resources Research Institute, NARC, Islamabad.

5. Kabir A (1999). Fertilizing with organic wastes to improve physical characteristics of soils. The Daily News International 26th April, 1999.

6. Anonymous (2011-2012). Agriculture statistic of Pakistan. 
7. Moshileh AMAL, Errebhi MA \& Motawei MI (2005). Effect of various potassium and nitrogen rates and splitting methods on potato under sandy soil and arid environmental conditions. Amir J Agric Sci 17(1): 01-09.

8. Khalil IA, Habib N \& Ghafoor A (1980). Yield and quality of potato as influenced by nitrogen and potash fertilizer.

9. Baishya LK (2009). Response of potato varieties to organic and inorganic sources of nutrients. $\mathrm{Ph}$. D. Thesis submitted to Visva-Bharati, West Bengal, India pp 99102.
10. Nyamangara J, Mugwira LM, Mpofu SE (2000). Soil fertility status in the communal areas of Zimbabwe in relation to sustainable crop production. J Sust Agric 16: 15-29.

11. Banin A \& Narorot J (1982). Trunk implanted zinc-bentonite as a source of zinc for apple trees. Plant and Soil 69(1): 85-95.

12. Minhas RS \& Sood A (1994). Effect of Inorganics and Organics on the Yield and Nutrient Uptake by Three Crop Rotations on an Acid Alfisol. Journal of Indian Society of Soil Science 42: 257-260. 